\title{
Sublittoral ecology of marine algae on the North Wales coast
}

\author{
ROGER M. SMITH \\ Marine Science Laboratories, Menai Bridge, Anglesey, N. Wales, U. K.
}

\begin{abstract}
KURZFASSUNG: Sublitorale Ókologie mariner Algen an der Küste von Nord-Wales. Uber die sublitorale Pflanzenwelt bei Anglesey und Caernarvonshire ist relativ wenig bekannt. Das Ziel unserer im Oktober 1964 begonnenen Taucharbeiten war daher, die Kenntnisse über Artengefüge, Verbreitung und vegetative sowie reproduktive Jahreszyklen zu vertiefen. Die Wirkungen von Temperatur, Licht, Wellenexposition und Sporenverbreitung wurden untersucht und zu den gefundenen Verbreitungswerten in Beziehung gesetzt. Es zeigte sich, daß die Westküsten $A$ und $B$ in 4 verschiedene Sublitoralregionen unterteilt werden können, während an den Ostküstenstationen eine einheitlichere Verbreitung vorherrschte. Die 4 unterscheidbaren Westküstenregionen waren der Laminarienwald, der Felsbereich unterhalb der Laminarien, das Bett loser Steine und das Sandbett mit Laminaria saccharina. Bei Station C hängt die Algenverbreitung mehr von der lokalen Topographie ab. Die Fortpflanzungszeiten der Algen erwiesen sich als abhängig von der Wassertiefe am Standort.
\end{abstract}

\section{INTRODUCTION}

Over Anglesey, Irish Sea, the prevailing wind is southwest; the west coast is more exposed to wave action than the east coast. The variation in sea water temperature is $11.5^{\circ} \mathrm{C}$, from $6.5^{\circ} \mathrm{C}$ in January to $18^{\circ} \mathrm{C}$ in July. The east coast generally is $1^{\circ} \mathrm{C}$ warmer at any time. At the stations where diving work has been carried out, there are no fresh water streams to effect a change in salinity. The sublittoral flora is relatively unknown when compared with littoral records. Specimens found in the drift material provide our only records (DAVEY 1953).

Figure 1 shows the position of the three stations described here: Station A, Trearddur Bay; station B, Porth Cwyfan; station C, Fedw Fawr. The littoral regions of stations $A$ and $B$ indicate a similar, severe degree of exposure to wave action. A sheltered bay at station B provides an interesting contrast to the exposed shore 100 metres away.

The shore of station $\mathrm{C}$ is composed of boulders about $20 \mathrm{~cm}$ in diameter. They are moved by wave action and support a restricted flora in the lower littoral only. A solid limestone ridge at the end of the beach supports a littoral succession of plants which suggests a moderate degree of wave action, i.e. Ascopbyllum is present in a small form. 


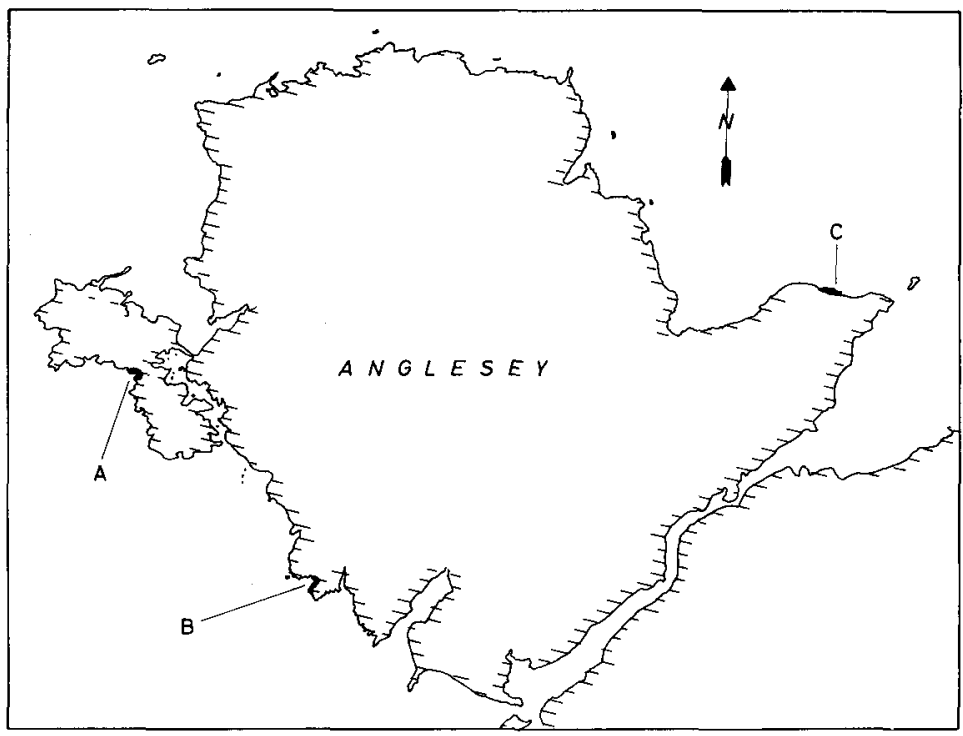

Fig. 1: The coast line of Angelsey (Irish Sea), showing the positions of the three stations examined

\section{EQUIPMENT AND METHODS}

This study was carried out using standard SCUBA equipment. A neoprene wet suit was worn to prolong working time. Dives were made at the sites throughout the year whenever weather conditions permitted. The limit of winter dives during which point useful work could be done was 1 hour. During dives notes were made on the environment of the collected plants from the aspect of (1) depth, (2) light intensity, (3) temperature, (4) substratum, (5) exposure to wave action. These were recorded as follows.

(1) Depth was measured with a temperature stabilized manometer depth meter calibrated in feet. On each dive the observed depth was corrected to a standard below extreme low water springs (ELWS).

(2) During the early part of the work only a subjective estimate of the visibility was possible, later, a mini-photometer in a waterproof case was used to obtain readings of incident light in lumens/square foot.

(3) A mercury thermometer was carried on the diving note board to record temperatures during the dive. Exceptionally, the temperature did vary with depth, at times when the water received several hours of continuous insolation, during a flat calm with still air. Then, the temperature at the surface was $1^{\circ} \mathrm{C}$ above a reading at 30 feet. At other times a surface reading gave a true record to the temperature throughout the working region.

(4) The substratum was recorded as the rock type with an estimation of the angle of slope and its aspect. An epiphyte was recorded with an identification of the host plant and the position it held on the host. 
(5) A small instrument designed and tested by Demetropoulos (1965) is being used to measure exposure to wave action. Early attempts to obtain readings were frustrated by loss of the instruments.

Initial work was to make a qualitative collection of plants from a series of five depth regions, $0^{\prime}$ to $10^{\prime}, 10^{\prime}$ to $20^{\prime}, 20^{\prime}$ to $30^{\prime}, 30^{\prime}$ to $40^{\prime}$, and below $40^{\prime}$. Exact depth readings were taken for some individuals. Plants were removed from the rock with the fingers or scraped with a knife. Total removal of plants was made in as many small different areas as possible in an attempt to obtain a complete record of the plants. Whenever possible the material was examined the day it was collected. The material was identified, notes were made on the vegetative and reproductive activity of the plants, and some attempts were made to determine the periods of active spore dispersal in the laboratory. During the infrequent periods of good visibility at all stations the general sublittoral topography was surveyed.

With the information gained from the qualitative work, methods were designed to describe the flora quantitatively. The structure of the vegetation, both in the sense of plant form and ecology, the limitations set by diving and the poor visibility in the water, resulted in the choice of two techniques. Greig-Smith (1964) and Kershaw (1964) were referred to at this point. (1) To describe the flora change with depth, line transects were carried out from the deepest point to the littoral zone. (2) To describe the rapid change in the populations during the summer, permanent quadrats were used.

The transect line was marked out using a plastic tape numbered at three metre intervals. Using a quadrat of area $1 / 16$ of a square metre, one sample of vegetation was removed from each station. Total clearance of plants was made from each quadrat. At each station a record was made of the depth, light intensity and slope (aspect and estimated angle of slope) and any other relevant information. Large Laminaria plants and their epiphytes were left in situ, a record of the number per quadrat being made. The material from each station was collected in a polythene bag and examined in the laboratory as follows: (1) The individual species were separated and counted. (2) All plants were examined for reproductive structures. (3) Each species was damp dried and weighed. Results were plotted as a histogram of biomass of each species along a scale representation of the topography of the transect.

In May 1966 permanent quadrats were placed in a region which was known to support a dense population of quick growing ephemerals in the summer months. Each quadrat was $50 \mathrm{~cm}$ square and was divided into 25 sub squares to facilitate the recording of the positions of the plants. A sheet of roughened yellow perspex divided as the quadrat was used to record the position of each individual. Light intensity measurements were made at the site of each quadrat.

It is intended to compare the climatic population in each region with the population of young sporelings which become established throughout the sublittoral zone. A species restricted to one particular region will have spores distributed throughout the littoral and sublittoral zones. It is almost impossible to obtain sublittoral rock samples for examination for the presence of sporelings. The substratum rock of stations A and $\mathrm{B}$ is precambrian which resists hammer blows even in the littoral zone. In the water the resistance to movement is so great that hammer strokes must be kept short. These strokes are of limited effect, the encrusting corallines may be dislodged but the rock 
usually crumbles into very small fragments of no value. Thus glass slides are relied upon to indicate the establishment of sporelings.

\section{RESULTS AND DISCUSSION}

In ecological terms station $C$ presents a contrast to stations $A$ and $B 1$, these two stations being similar (light penetration curves see Figure 4). Four regions could be recognized at stations $A$ and $B 1$, each region bearing a distinct population of plants (Figures 2, 3; Table 1): (1) The Laminaria forest; (2) The rock outcrops below 25 feet

Table 1

Key to species in Figures 2, 3, 7, 8, 9

\begin{tabular}{|c|c|c|c|c|c|}
\hline 0 & Cladophora rupestris & 14 & Laminaria digitata & & Halopteris, Aglazonia \\
\hline 1 & Blue-green mat & 15 & Laminaria byperborea & & (Cutleria) \\
\hline 2 & Porphyra & 16 & Corallina & 26 & Dictyota \\
\hline 3 & Ulva & 17 & Furcellaria & 27 & Dictyopteris, Halopteris \\
\hline 4 & Enteromorpha & $17 a$ & Polyides & 28 & Naccaria, Halarachnion, \\
\hline 5 & Pelvetia & 18 & Plocamiun & & Taonia \\
\hline 6 & Fucus spiralis & 19 & Heterosiphonia & 29 & Halidrys \\
\hline 7 & Fucus vesiculosus & 20 & Delesseria & 30 & Laminaria saccharina \\
\hline $7 a$ & Fucus vesiculosus & 21 & Gracilaria & 31 & Cladostephus \\
\hline 8 & Fucus serratus & 22 & Callopbyllis & 32 & Ceramium \\
\hline 9 & Ascophyllum nodosum & 23 & Cryptopleura & 33 & Abnfeltia \\
\hline 10 & Himanthalia & 24 & Rbodymenia, mein- & 34 & Phyllophora \\
\hline 11 & Polysiphonia nigrescens & & branoptera, Phycodrys & & membranifolia \\
\hline 12 & Chondrus & 25 & Chorda, Uloa, Entero- & 35 & Polysipbonia elongata \\
\hline 13 & Alaria & & morpha, Tilopteris, & 36 & Griffithsia \\
\hline
\end{tabular}

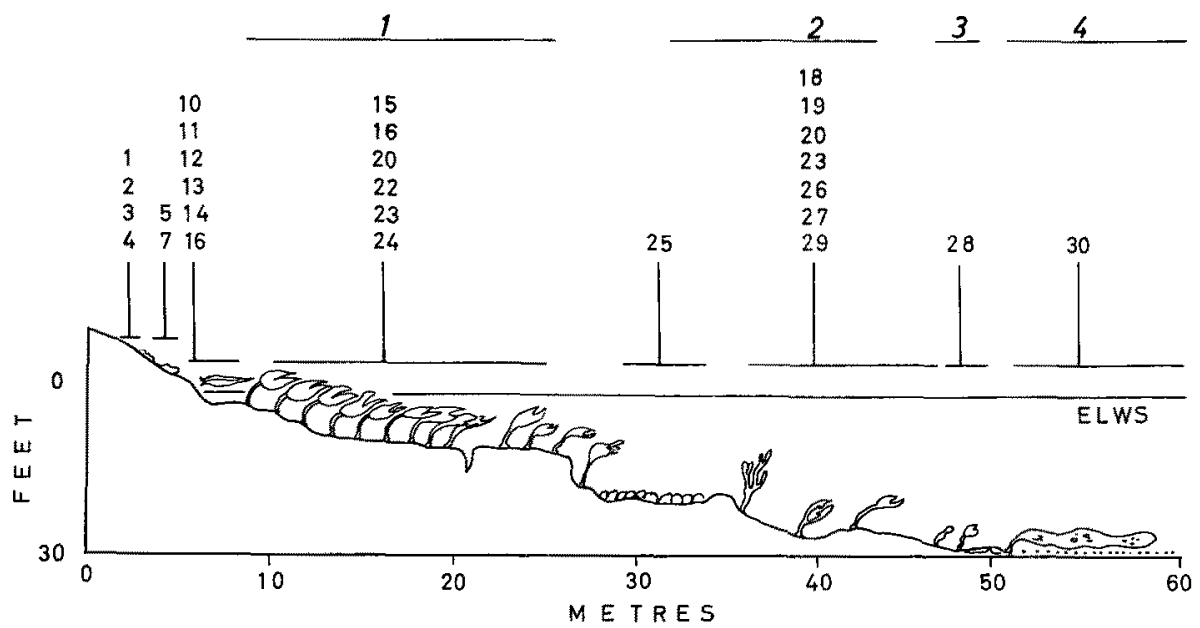

Fig. 2: Profile of station A. Small numbers above the profile indicate the more frequent species (Table 1). Large figures and horizontal lines show the limits of the four regions described. (Profile treatment after Neushul 1965) 


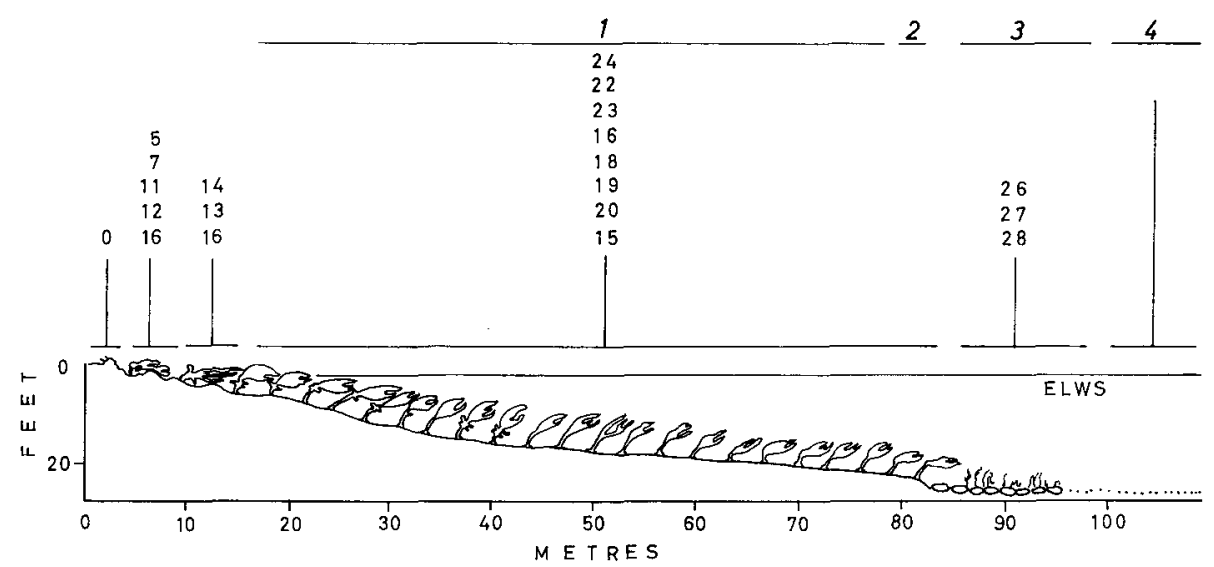

Fig. 3: Profile of station B. Small numbers above the profile indicate the more frequent species (Table 1). Large figures and horizontal lines show the limits of the four regions described. (Profile treatment after Neushul 1965)
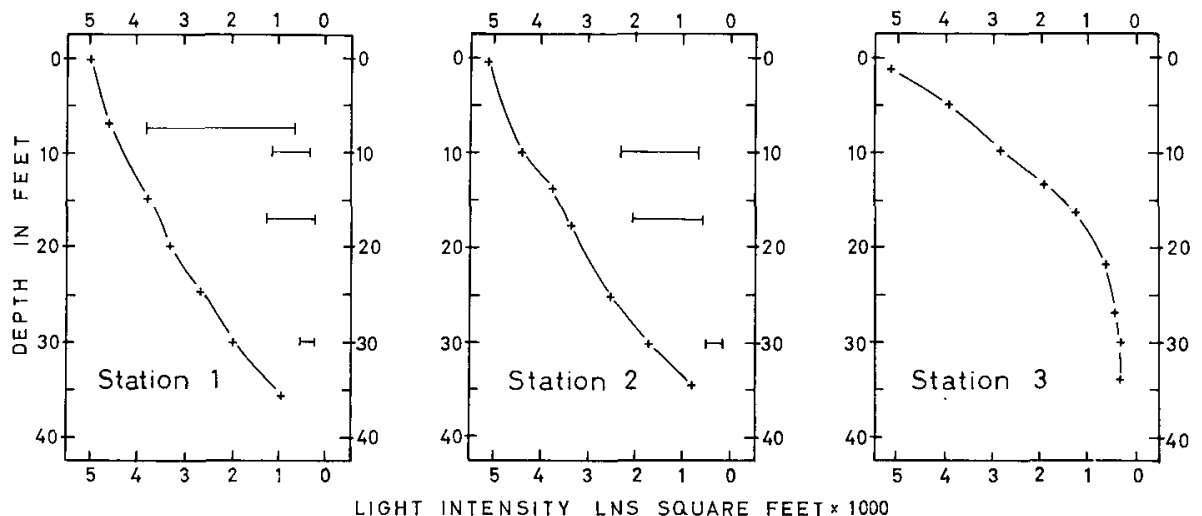

Fig. 4: Light penetration curves made with a mini-photometer in a waterproof housing. Neutral filters were used to extend the range of the instrument, simultaneous light readings could then be taken just below the surface. Horizontal lines indicate the light intensity under Laminaria shade at various depths. The length of the line is a direct measure of the variation in light intensity due to movements of the plants in calm weather

and outside the Laminaria forest, not subject to shading by the plant canopy; (3) The bed of loose stones; (4) The sea bed of sand.

(1) The Laminaria for est is formed by a dense growth of Laminariabyperborea, at a density of up to 12 plants per $1 / 16$ of a square metre. The plants grow to a height of one metre. The forest extends from 2 feet to 25 feet below ELWS. Beyond this depth clumps of Laminaria plants are present, capping the tops of rocks. At all depths the presence of the plants appears to be limited by slope. Rocks with a slope exceeding an estimated angle of $60^{\circ}$ were not colonized. This is in contrast to the observations of KaIN (1962), who found Laminaria growing on vertical faces. The presence of Lami- 
naria plants produces a canopy of blades which reduces the light intensity by a factor varying with depth. Light intensity measurements taken with a photometer gave the following results:

$\begin{array}{cc}\text { Depth (feet) } & \text { Shade factor } \\ 10 & 3 \\ 12.5 & 4 \\ 17.5 & 10 \\ 22.5 & 12 \\ 30 & 20\end{array}$

The shade factor is the ratio between the light intensity in open water and the light intensity at the base of the Laminaria plant, both readings taken at the same depth. At least two causes contribute to this effect. (1) with increasing depth the pattern of light distribution changes. In shallow water internal reflection from the sea surface results in a general bright illumination. At depth, the greatest illumination is received from a narrow angle near the vertical, thus the blade of the plants reduces a greater proportion of the incident light. (2) At depth, the Laminaria plants are shorter and the blades, though smaller, present a comparatively larger shading area.

This shading effect limits the distribution of algae in this region. Comparisons can be made between rock surfaces which are subject to a difference in light intensity and the cover of haptera only. The following is the result of collections from $15 \mathrm{Al}$ below ELWS: (a) Among the Laminaria haptera, shaded by the canopy: Lithopbyllum, Corallina, Cryptopleura, Phycodrys, Membranoptera, Rbodymenia, Cladophora pellucida, Chaetomorpha, Callophyllis. (b) From a rock surface outside the forest in open water, clear of shading, at the same depth as (a): Lithopbyllum, Corallina, Cryptopleura, Heterosiphonia, Plocamium, Sphaerococcus, Griffithsia, Delesseria, Dictyota, Dilsea, Hypoglossum.

These two populations differ significantly. Before it can be assumed that light intensity is the only contributing factor, two points must be made. The light intensity beneath the forest canopy is variable over a short period of time as the plants move in the sea wells. It may reach the light intensity of open water at the same depth; the net effect of the canopy is to reduce the quantity of light energy reaching the rock below, but sporelings are exposed to relatively high light intensities for short periods (Fig. 4). Furthermore, species which appear outside the Laminaria forest occur to a depth at which the light intensity is below that found under the maximum canopy shade at the same depth. Thus these plants are capable of growing in a light regime similar to that of the Laminaria forest. Smooth glass slides within the Laminaria forest showed a settlement of the following species: Rhodymenia, Phycodrys, Acrochaetium, Chaetomorpha, Polysiphonia brodeii, P. urceolata, Griffithsia, Ceramium rubrum, Plocamium, Heterosiphonia, Lithophyllum, Laminaria.

This shows that species not found in a mature state in the Laminaria forest may be present as sporelings. Sporelings of these species can be found on the haptera of the Laminaria plants. Experiments including removal of blades, stipes and total clearance of haptera are at present under way, designed to give a picture of the subsequent colonisation by algae. 
The epiphytes of the stipe and blade of Laminaria byperborea form a distinct population and it is hoped to give a detailed account of this subsequently. Two points have emerged however: (1) Apart from the tendency of Rhodymenia palmata to keep to the upper part of the stipe, there is no distinct zonation of species. The proportions of the algae change with depth in respect of biomass (Fig. 5). (2) The epiphytes showed a consistent orientation in relation to the oval section of the stipe in shallow water (Fig. 6).

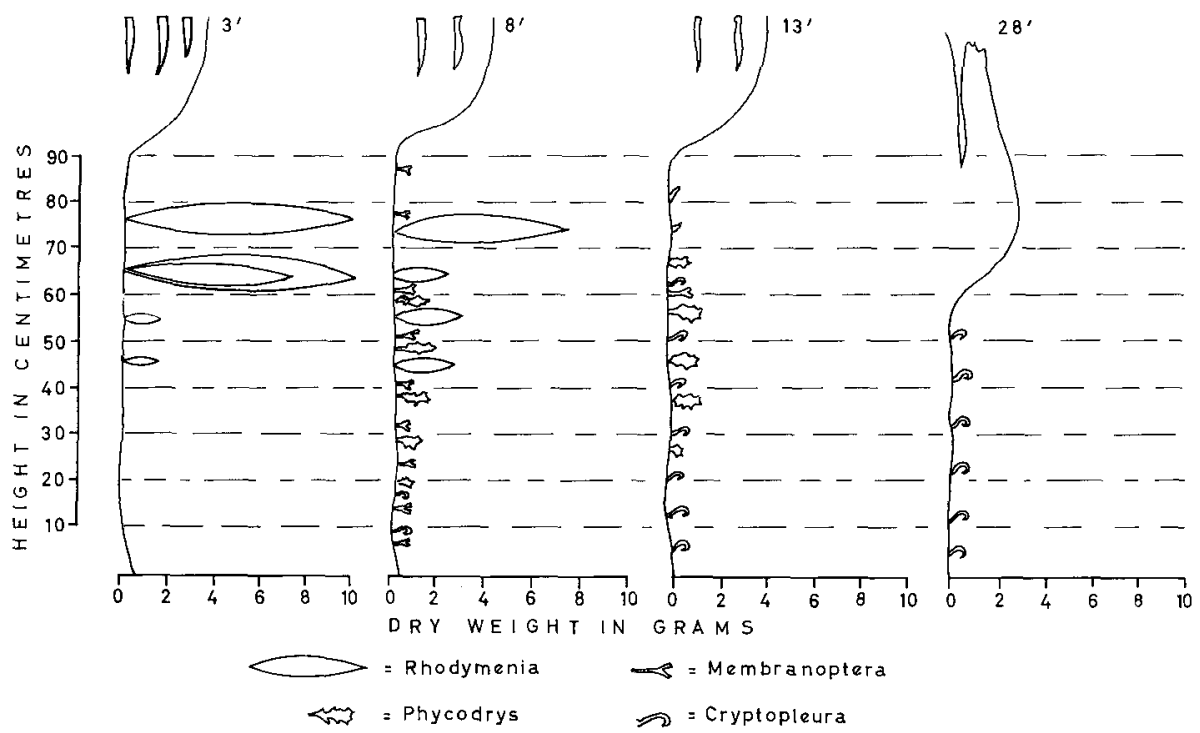

Fig. 5: Portions of Laminaria plants are diagrammatically represented. The distribution of epiphytes along the stipe is shown. The length of the epiphyte, gives a measure of the biomass (in g dry weight) of each species to per ten centimetre portion of stipe. The depth of origin of the plant is indicated by $3^{\prime}, 8^{\prime}, 13^{\prime}, 28^{\prime}$ measured from ELWS

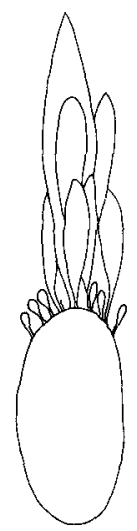

Fig. 6: Diagrammatic cross section of the stipe of Laminaria byperborea showing the distribution of epiphytes around the circumference. The plant was collected in April, 1965, from $8^{\prime} \mathrm{ft}$ below ELWS. No explanation for this distribution has yet been found 
In the Laminaria forest there are local changes of flora due to slope and substratum changes. At station $\mathrm{A}$, basins are found forming a clearing which is not subject to Laminaria shading (Fig. 7, St. A). Typically they have steep sides and a floor of loose stones. The rock sides support a flora of Delesseria sanguinea, Cryptopleura ramosa and Lithophyllum sp. The loose stones support a population of Enteromorpha compressa, Cladophora pellucida, Polysiphonia urceolata and Desmarestia aculeata in winter. During the summer months the following species were present: Ulva lactuca, Enteromorpha compressa, E. intestinalis, Tilopteris mertensii, Polysiphonia urceolata, Chorda filum, Halopteris filicina and the Aglazonia stage of Cutleria multifida. These stones were sheltered and do not move during storms.

At station $\mathrm{B}$, the troughs between the ridges are subject to sand scour (Fig. 7, St. B). The only species found in these troughs were Polysiphonia nigrescens, Rhodomela confervoides and Cladostephus verticillatus. The epiphytic population of the last species was considerable but none of the epiphytes were more than $1 \mathrm{~cm}$ long on a plant $10 \mathrm{~cm}$ high.
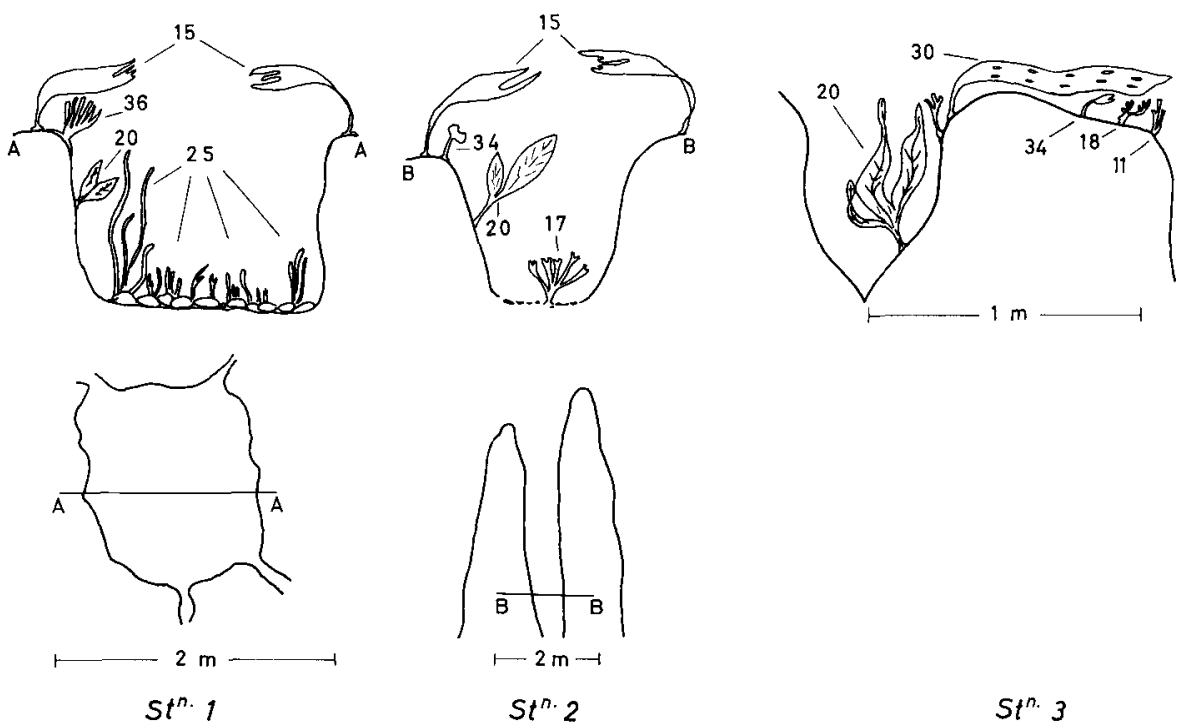

$5 t^{n \cdot 3}$

Fig. 7: Profile of a stone floored hollow at station 1 and a sand floored channel at station 2. The former is sheltered, the latter is exposed to wave action. Species present are indicated digrammatically and by reference to Table 1 . Plan view is shown below each figure. The profile of a large boulder from station $C$ is shown

(2) The rock out crops 25 feet below ELWS, free from Laminaria, support a population of plants consisting of perennials and summer ephemerals. A species list prepared from qualitative collections, by analysis of throws with a 1/16th of a square metre quadrat and transect data is given here: Pe ren $\mathrm{nials}$ : Heterosiphonia, Plocamium, Delesseria, Cryptopleura, Chondrus, Chaetomorpha, Dictyopteris, Halopteris, Griffitbsia, Dilsea, Corallina, Pbyllophora brodeii, Hypo- 
glossum, Rbodomela, Antithamnion, Cladophora, Halidrys, L. byperborea. A n n u a ls: Dictyota, Sphondylothamnion, Taonia, Naccaria, Saccorbiza, Halurus, Brongniartella.

It has been found that the occurrence of the summer ephemerals does not show a similar frequency of species each year. The most obvious example of this is Naccaria wiggii. Only 12 plants were found during the summer of 1965 . In 1966 the plant is abundant. During diving collections at Bardsey by Dr. KNIGHTJoNEs in July 1955 (JONEs 1955), it was found that the tetrasporic and cystocarpic phases of Brongniartella were separated spatially by some $10 \mathrm{~m}$. Tetrasporic plants were confined to a depth of $15 \mathrm{~m}$ and cystocarpic plants were confined to a depth of $25 \mathrm{~m}$. During the present work in this region it was noted that on the 20th August 1965 at station A, Brongniartella was found at twenty feet in a region of dense cover of Desmarestia and was entirely tetrasporic. At 30 feet Brongniatella was found in an open region entirely cystocarpic. Further it has been noted that a number of algae, which can be found both in shallow water and to the limit of algal growth, show a difference in the period of fruiting with depth. Generally the deeper the plant grows, the longer the period of fruiting.

(3) A bed of loose stones lies beyond the rock outcrops consisting of flattened discs up to $6 \mathrm{~cm}$ in diameter and $2 \mathrm{~cm}$ thick. The stones are subject to sand scour and movement during the winter. Marked stones changed position between dives which were separated by storms. During the winter of 1964-65, stones examined in the laboratory showed sporelings of Plocamium (mature plants were fertile in shallower water); Sphacelaria and Desmarestia were also present. From material grown in the laboratory and compared with these sporelings, the estimated age of both Plocamium and Sphacelaria was three weeks. At the end of July a population of plants appeared which consisted of plants all under one year old: Sphacelaria radicans, S. plumula, Polysiphonia nigrescens, P. urceolata, Delesseria, Plocamium, Cryptopleura, Chaetomorpha, Acrochaetium, Cladophora glaucescens, Phycodrys, Membranoptera, Desmarestia ligulata, Brongnartella, Halorachnion, Taonia, Dictyota, Sporochnus, Scinaia, Sphondylothamnion, Laminaria saccharina. This list is similar to a species list from an unstable bottom examined by KarN (1960).

The growth of most summer ephemerals commences in mid-June and becomes conspicuous by late July, the time at which the fruiting commences. The rapidity with which the population changes, resulted in the choice of permanent quadrats to record the flora.

(4) The se a bed of s and lies beyond the loose stones; it is a floor of sand which extends into open water. The sand is formed into sand waves with a wave-length of $14 \mathrm{~cm}$. Occasionally individuals of Laminaria saccharina are found up to $1 \mathrm{~m}$ in length. At station A, $100 \mathrm{~m}$ seaward in the sand, rocks 5 to 6 inches in diameter and up to one and $1 \frac{1}{2} \mathrm{~m}$ high project from the sand. Many of these supported a population of Phyllophora brodeii.

Transect B2 (Fig. 8) was made from the exposed sand bed to the sheltered shore, characterized by shallow pools. It indicates the change that can take place in the flora of an area over a short distance. Alaria esulenta, a plant characteristic of exposed shores, is prominent in transect B1, $100 \mathrm{~m}$ from B2; it is entirely absent in B2 and is 
replaced by sheltered shore forms of Fucus serratus (50 cm in length) and Ascophyllum nodosum (1 $\mathrm{m}$ in length).

Station $C$ is on the East coast of Anglesey. The shore is surrounded by high cliffs. The boulder beach shelves steeply and supports a population of Ulva and Porphyra limited to the lower littoral. The sublittoral region contrasts with that described for

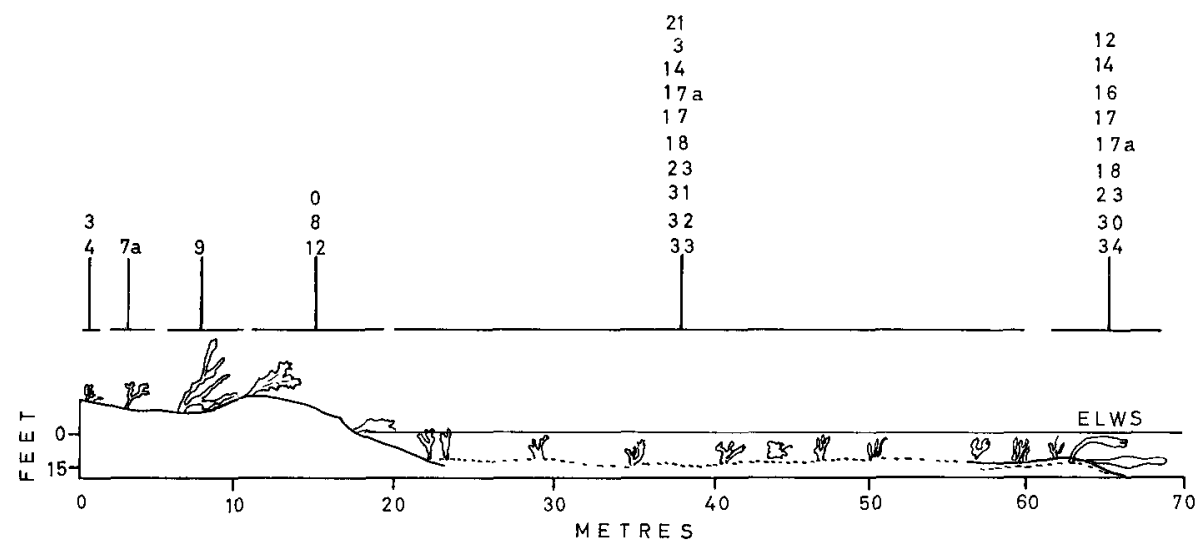

Fig. 8: Profile of station B2. From a transect taken June, 1966. Species recorded by diagram and by reference to Table 1 . This transect was run parallel and $100 \mathrm{~m}$ away from $\mathrm{B} 1$ in a sheltered region of a bay

stations $\mathrm{A}$ and $\mathrm{B}$ - the Laminaria forest is absent. The visibility in the water is always poor, generally 2 feet visibility at 10 feet depth. This practical difficulty makes detailed study very limited. Light penetration curves contrast with light curves from stations A and B (Fig. 4).

The sea floor is made up of a bed of boulders greater than $1 \mathrm{~m}$ in diameter. The distribution of the flora seems to be more dependant upon the local topography of the boulders (Fig. 7, St. 3; Fig. 9). The following species were present: Laminaria digitata, L. saccharina, Delesseria sanguinea, Pbycodrys, Phyllophora membranifolia, Polysiphonia nigrescens, P. elongata, Chondrus, Furcellaria, Griffithsia, Cryptopleura. In July 1966 a young fucoid was seen at 15 feet below ELWS; it was $3 \mathrm{~cm}$ high. The light intensity was 100 lumens - per square foot -1/20th of the value of the surface intensity. Large quantities of mud are present suspended in the water and lying on the rock surface.

Individuals of Delesseria, Pbycodrys, Cryptopleura and Phyllophora membranifolia were generally better developed vegetatively than plants from the same depths at stations $\mathrm{A}$ and $\mathrm{B}$. The distance between individuals being greater, however, this still results in a lower biomass of algae per unit area at any particular depth. Great difficulty was found in measuring an absolute value for biomass per unit area because of the irregularity of the substratum. No area contained within the quadrat was flat, resulting in a larger area being sampled and a consequent exaggeration of results.

A biotic factor in the nature of grazing animals is present in the sublittoral zone. 
Animals have been found present at stations A and B. A gastropod, Patina pellucida, attacks the stipe of Laminaria byperborea at the base and at the growing region at the junction of blade and stipe; occasional plants of Laminaria lose the blade and the top of the stipe becomes hollow. There is a subsequent change in the epiphyte population

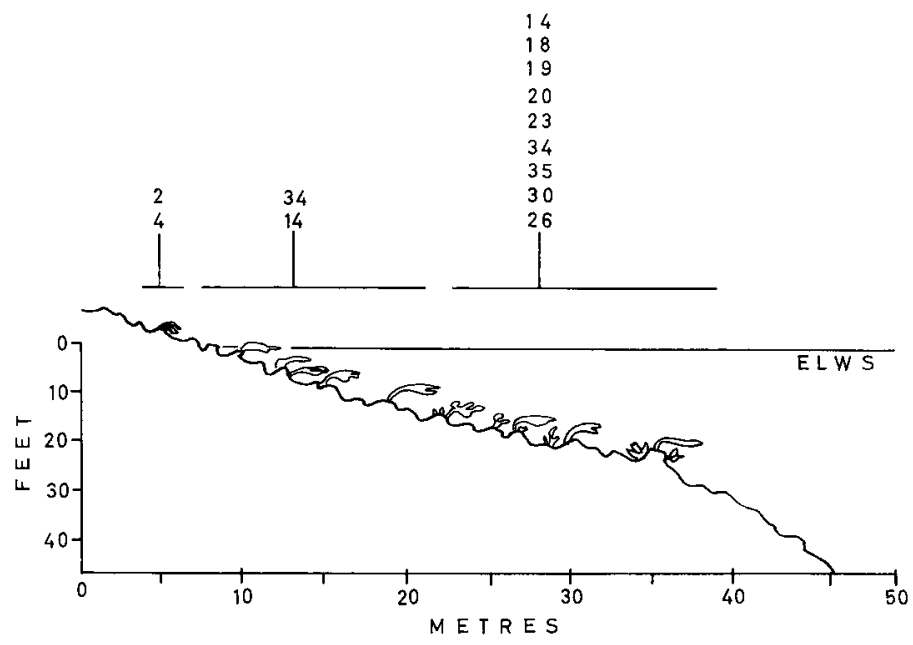

Fig. 9: Profile of station C. A moderately exposed beach composed of limestone blocks. Plants recorded are shown diagrammatically and by reference to the numbered list of algae in Table 1. (Profile treatment after Neushur 1965)

of the stipe. Species not frequently found as epiphytes are found growing on the stipes of these "decapitated" plants. Ptilota plumosa, Polysiphonia urceolata and Plocamium vulgare are examples of such invaders.

Most Laminaria that were examined had a hollow base inside the ring of haptera. This was infested with Patina which had migrated down the stipe. The base of the stipe may become so weak due to grazing that it is easily broken and may be torn up by heavy swells. Rotting haptera can be seen in the Laminaria forest, the upper part of the plant could have suffered this fate.

Many of the cartilagenous weeds from the sublittoral zone show obvious signs of grazing. The radula marks of gastropods can be recognised. Callistoma zyzipbinum has been found grazing on rock with a low sward of algae, mainly sporelings, established.

A population of the Ophistobranch, Aplysia punctata was present throughout the sublittoral region until July 1965 . This animal has considerable grazing capacity. The population probably exceeded 300 individuals during the summer, in an estimated area of $30 \mathrm{~m}^{2}$. It was found grazing on Plocamium, Heterosiphonia and Cryptopleura.

Bryzoans encrust many plants with perennial portions at all depths. The most frequently found species belonged to the genus Electra. Bryzoans showed more extensive growth in terms of area covered at station $C$. The annual portion of the frond was thickly encrusted by August. Similar plants were still clear at stations A and $\mathrm{B}$. 


\section{SUMMARY}

1. Diving work carried out between April 1964 and July 1966 on the North Wales coast (Anglesey) showed that the west coast stations A and B could be divided into four distinct sublittoral regions, the east coast station showed a more irregular distribution of the flora.

2. The four distinct regions were: The Laminaria forest, the rock below the Laminaria zone, the bed of loose stones supporting algae in summer, and the bed of sand supporting Laminaria saccharina.

3. The distribution of algae at station $\mathrm{C}$ was more dependant upon the local topography of the boulders making up the sea bed.

4. There was a difference between the fruiting periods of algae growing at a great depth and in the shallow water.

\section{ACKNOWLEDGEMENTS}

I wish to thank Mr. N. Woodhead, Department of Botany U.C. N. W., for his help and encouragement in regard to the conception of this study. Professor CRISP gave helpful advice and criticism during the course of the work. My supervisor, Dr. W. E. JonEs gave his time and endless enthusiasm in discussing the path of the work, identifying the material and giving advice on the culture of spores in the laboratory. His key to the genera of seaweeds was referred to continuously (JONEs 1962).

During diving collections Dr. T. H. Careroot gave me advice from his own diving experiences and acted as diving companion. Miss S. DenT provided essential assistance during diving transect work, in both the littoral and sublittoral, doubling the work completed per dive. The first 12 months of this work was self-financed and thanks are due to all who made this possible. The project is continuing under a grant from N.E.R.C.

\section{LITERATURE CITED}

Davey, A. J., 1953. Seaweeds of Anglesey and Caernarvonshire. NWest. Nat. 1953 (Sept.), $417-434$.

Demetropoulos, S., 1965. Measurement of wave action. M. Sci. thesis U. W.

GREIG-SMrTh, P., 1964. Quantitative plant ecology. Butterworth, London, 156 pp.

Jones, W. E., 1956. The littoral and sublittoral marine algae of Bardsey. Rep. Bardsey Bird Fld Obs. 1955, 40-51.

- 1962. A key to the genera of the British seaweeds. Fld Stud. 1 (4), 1-32.

KaIN, J. M., 1960. Direct observations on some Manx sublittoral algae. J. mar. biol. Ass, U.K. 39, 609-630.

- 1962. Aspects of the biology of Laminaria byperborea. 1. Vertical distribution. J. mar. biol. Ass. U. K. 42, 377-385.

Kershaw, K. A., 1964. Quantitative and dynamic ecology. Elsevier, Amsterdam, 178 pp.

Neushul, M., 1965. Scuba diving studies of the vertical distribution of marine plants. Botanica gothoburg. 3, 161-176. 


\section{Discussion following the paper by SмIтH}

LüNING: Do you find epiphytes on the stipes of Laminaria byperborea even in the dense forests?

Sмiтн: In the dense forest of Laminaria hyperborea the stipes of the plants bear epiphytes. These epiphytes differ in quantity and distribution from the epiphytes found on isolated plants of Laminaria hyperborea. Loss of the Lamina of Laminaria results in very dense growth of epiphytes on the upper portion of the stipe in dense forests.

KaIN: Have you actually found areas of rock denuded of Laminaria byperborea which you can attribute to the activity of Patina pellucida?

SмIтH: On one occasion five groups of decaying haptera from Laminaria byperborea were found within an area of $1 / 10 \mathrm{~m}^{2}$. More often individual remains of holdfasts are found within the forests. Evidence to suggest that the loss of these plants was due to infestion by Patina pellucida is as follows. (1) The Limpet Patina pellucida is abundant in its young form throughout the forest. (2) Harvested stipes show very high occurrence of the limpet in the base of the stipes. In this position the limpet can weaken the base of the stipe so that a small force is sufficient to break the plant off at holdfast level. (3) Large numbers of Laminaria byperborea accumulated in the sheltered gulley at the end of the bay. The bases of these plants had large basal cavities as a result of Patina activity. It is probable that the plants have been torn up during storm, the weakened stipe base being incapable of resisting the drag of the stipe blade. Whilst there are no large areas of rock cleared by the activity of Patina, there is a continuous loss of Laminaria individuals from the forest as a result of infestation by this limpet.

ANGEL: Why do you think the slope is important in the distribution of Laminaria byperborea?

SMrTH: From all the observations made during diving it was evident that slope or some factor correlated with slope affects the distribution of Laminaria byperborea. At the present time it is not known at which point in the life history of the plant the effect of the slope determines the distribution of Laminaria. The local slope in the region of haptera can be very variable. It may reach the vertical within the diameter of the holdfast. It is the gross angle of slope which seems to affect the distribution of the Laminaria. 